\title{
Mobilising private adaptation finance: developed country perspectives
}

\author{
W. Pieter Pauw ${ }^{1,2,3}$
}

Accepted: 13 December 2016/Published online: 3 January 2017

(C) The Author(s) 2017. This article is published with open access at Springerlink.com

\begin{abstract}
The private sector is one of the sources of finance included in developed countries' pledge in the UN climate negotiations to mobilise $\$ 100$ billion annually by 2020 to support developing countries' efforts to address climate change. For adaptation in particular, it remains unclear what mobilised private finance is. Research so far has focused on its potential and experiences in developing countries, but not on the arguments of those who introduced and continue to advocate private adaptation finance: developed countries. This paper investigates the positions of developed countries and development banks and agencies. In particular, it aims to identify whether those actors can reach a common understanding of private adaptation finance that minimises norm conflicts in a fragmented climate finance system. Empirically, the paper examines the Biennial Reports and submissions on Strategies and Approaches for Mobilising Scaled-up Finance of six developed country parties, as well as data from interviews with experts from development banks and agencies. The analysis finds a number of discrepancies between these sets of actors, for example on motivations for and modes of private sector involvement. This discrepancy is the result of ambiguity around the concept of private adaptation finance in a highly fragmented climate finance architecture. This ambiguity is problematic when the aim of mobilising private adaptation finance is to contribute to the $\$ 100$ billion commitment. However, if the aim is adaptation in practice, both ambiguity and fragmentation might actually make the climate finance system more inclusive and innovative.
\end{abstract}

Keywords Adaptation · Private finance $\cdot$ Climate finance $\cdot$ Fragmentation $\cdot$ Climate policy

W. Pieter Pauw

pieter.pauw@die-gdi.de

1 Deutsches Institut für Entwicklungspolitik/German Development Institute (DIE), Tulpenfeld 6, 53113 Bonn, Germany

2 Copernicus Institute of Sustainable Development, Utrecht University, Heidelberglaan 2, 3584 CS Utrecht, The Netherlands

3 Stockholm Environment Institute (SEI), Linnégatan 87D, 11523 Stockholm, Sweden 


$\begin{array}{ll}\text { Abbreviations } \\ \text { ADB } & \text { Asian Development Bank } \\ \text { AfD } & \text { Agence Française de Développement } \\ \text { BR } & \text { Biennial Report } \\ \text { DAC } & \text { Development Assistance Committee } \\ \text { DEG } & \text { Deutsche Investitions- und Entwicklungsgesellschaft } \\ \text { EIB } & \text { European Investment Bank } \\ \text { GCF } & \text { Green Climate Fund } \\ \text { GEF } & \text { Global Environment Facility } \\ \text { GIZ } & \text { German Society for International Cooperation } \\ \text { IDB } & \text { Inter-American Development Bank } \\ \text { IFC } & \text { International Finance Corporation } \\ \text { JBIC } & \text { Japan Bank for International Cooperation } \\ \text { JICA } & \text { Japan International Cooperation Agency } \\ \text { KfW } & \text { Kreditanstalt für Wiederaufbau/KfW Development Bank } \\ \text { MRV } & \text { Measurement, reporting and verification } \\ \text { MSF } & \text { Strategies and Approaches for Mobilising Scaled-up Finance } \\ \text { PPCR } & \text { Pilot Programme for Climate Resilience } \\ \text { OECD } & \text { Organisation for Economic Cooperation and Development } \\ \text { UNDP } & \text { United Nations Development Programme } \\ \text { UNEP } & \text { United Nations Environment Programme } \\ \text { UNFCCC } & \text { United Nations Framework Convention on Climate Change } \\ \text { USAID } & \text { United States Agency for International Development } \\ & \end{array}$

\section{Introduction}

Climate change already impacts natural and human systems on all continents and across the oceans (IPCC 2014). Developing countries are historically least responsible for the emissions that cause climate change, but most vulnerable to its impacts (Ayers 2011), with global costs of adaptation estimated at US $\$ 280$ to $\$ 500$ billion by 2050 (UNEP 2016). ${ }^{1}$ Developed countries recognise the need for substantial financial resources to meet the costs of adaptation and mitigation, and pledged to mobilise $\$ 100$ billion annually by 2020 at the UN climate negotiations in 2009 (UNFCCC 2009: Decision 2/CP.15, paragraph 8; special issue Editorial).

This paper focuses on one of the most contested aspects of climate finance: private adaptation finance. Research on this topic so far focuses on its potential and experiences in developing countries (cf. Atteridge 2011; Intellecap 2010; Pauw 2014; Pauw et al. 2015), but not on the arguments of those who introduced and continue to advocate it. This paper aims to fill this research gap by investigating the positions of developed countries as well as development banks and agencies. In particular, it aims to identify whether these actors can reach a common understanding of private adaptation finance that minimises norm conflicts in a fragmented climate finance system.

The "private sector" is a broad concept. This paper refers to it as all for-profit non-state organisations and individuals in all economic sectors. In adaptation, this ranges from smallholder farmers all the way to multinationals, for instance in construction or finance.

\footnotetext{
${ }^{1}$ All monetary values are in US\$.
} 
These actors can implement and/or finance adaptation. Private adaptation finance is fundamentally different from and more complex than private mitigation finance. The cost per ton of abated greenhouse gas emissions is a useful proxy to measure the effectiveness of mitigation investments. The concept of adaptation, however, remains characterised by epistemic ambiguity (see Hall, this issue), and its impacts are hard to measure. Adaptation is carried out amid uncertainty about actual and projected climate change, and costs potentially remain with the investor, whereas benefits are often largely public (Abadie et al. 2012; Atteridge and Dzebo 2015; Project Catalyst 2010).

Although climate finance does not have a broadly accepted definition (Brunner and Enting 2014; UNFCCC Standing Committee on Finance 2014), first attempts have been made to define (mobilised) private climate finance (see Jachnik et al. 2015; Brown et al. 2015; Vivid Economics 2015). The best definition of publicly mobilised private adaptation finance is probably from Brown et al. (2015: IV): "private finance invested as a result of adaptation-related public interventions, which can typically take the form of finance or policies". However, this definition does not resolve contentious issues about the type of actors (which could include institutional investors, insurers, banks, philanthropy, and other instrument) or finance instruments (which could include bank loans, bonds, and insurance). Furthermore, the definition does not explain how to prevent public interventions from creating inappropriate subsidies or crowding out private actors.

Developing countries are sceptical about private adaptation finance: the potential is unclear given the limited experience, and many countries fear that private finance will replace public finance (cf. Pauw 2014; Surminski 2013). The work programme on longterm finance of the United Nations Framework Convention on Climate Change (UNFCCC) points out that the current mix of public and private funds mobilised may not meet the needs for adaptation finance (UNFCCC 2013a). It also shows that private finance is generally inclined towards mitigation, and that an emphasis on private finance could further disadvantage adaptation (see also Whitley and Mohanty $(2012,2013)$ for empirical evidence on this). Finally, the report calls for improved transparency on climate finance by defining mobilised private finance in the context of the $\$ 100$ billion commitment (UNFCCC 2013a).

Despite the unclear definition and limited experience, developed countries push for mobilising private climate finance. For example, in 2008 they established the Pilot Programme for Climate Resilience (PPCR), which explicitly aims to mobilise private cofinancing for adaptation projects in developing countries. In 2009, developed countries refused to support the Copenhagen Accord if the private sector was not included as a source of climate finance (Romani and Stern 2011). And in 2013, after a push by developed countries in particular, the Green Climate Fund (GCF) established a Private Sector Facility, which targets international businesses and capital markets to catalyse clean investments and innovation.

As outlined in the special issue Editorial, effective mobilisation of private investments in adaptation partly depends on the governance architecture of the "climate finance system" at large. The term architecture does not presume that there is one architect or regulation from one (dominant) regime only: it is a neutral term and allows for an analysis of policy domains with multiple regimes (Biermann et al. 2009). The climate finance system is highly fragmented. Fragmentation is an inherent structural characteristic of present-day international relations (Zelli and van Asselt 2013: 3). Biermann et al. (2009) describe fragmentation as a continuum ranging from a synergistic (higher) to a conflictive (lower) degree of fragmentation. Their typology of fragmentation of governance 
architecture highlights the importance of "institutional integration", "actor constellations", and "norm conflicts" (see also special issue Editorial).

- Institutional integration the UNFCCC is the core of the climate finance architecture. This is where countries decide on climate finance aims, targets, and proceedings. However, this core would be unable to address its main objective-to prevent dangerous climate change-and therefore dysfunctional without its wider spheres (or categories) of institutional fragmentation, including specialised UN agencies (e.g. the United Nations Environment Programme (UNEP) and the United Nations Development Programme (UNDP)); other multilateral as well as bilateral institutions (including the banks and agencies from which experts were interviewed for this paper-see Sect. 2), climate funds, climate trust funds, etc.

- Actor constellations the above-mentioned spheres and actors are only loosely integrated. Beyond the bifurcation between developed countries (providing finance) and developing countries (receiving finance), many actors focus on certain regions (e.g. the Asian Development Bank) or groups of countries (e.g. the Least Developed Countries Fund). Other actors have particular roles, such as funding projects (where the GCF and the many other climate funds also fund particular types of projects) or tracking climate finance (e.g. the Organisation for Economic Cooperation and Development (OECD) and Climate Policy Initiative).

- Norm conflicts between the above-mentioned institutions in the climate finance system are abundant. This paper focuses on the norm conflict on private adaptation finance.

The two sets of actors in the climate finance system studied in this paper (developed countries and development banks and agencies) are crucial in the climate finance system's architecture. Their control over financial resources allows them to dominate much of the policy process and to lead the debate. Developed countries provide public climate finance and insisted on private finance as a source of the $\$ 100$ billion commitment. Development banks and agencies, including those represented by the respondents (see Sect. 2), were originally established to serve development purposes and have expanded their tasks to also mobilise, manage, and provide climate finance in the last decade in particular. In that sense, they are "inherited" from the development regime (see also Delina, this issue). They are predominantly owned by developed countries and affiliated with their perspectives on private adaptation finance. As empirical data, this paper first analyses political statements of six developed countries based on recent 24 submissions to the UNFCCC. Second, the distilled information is triangulated and deepened through expert interviews with development banks and agencies. It is beyond the scope of this paper to describe individual projects and their effectiveness. Instead, this paper focuses on institutional perspectives on private adaptation finance in order to accommodate the views of the targeted sets of actors in the climate finance system.

The next section describes the research method in detail. Section 3 provides the results of the document analysis and the interviews in four subsections: (1) defining the mobilisation of private adaptation finance and motivations to do so; (2) early experiences; (3) actors, instruments, and modalities used; and (4) tracking of private finance in the context of the $\$ 100$ billion commitment. Section 4 concludes. 


\section{Method}

This paper first analyses four sets of documents from Canada, the EU, Japan, New Zealand, Norway, and the USA on their perspective on private adaptation finance: their Biennial Reports (BR) of 2014 (BR1) and 2015/2016 (BR2); ${ }^{2}$ and their submissions on Strategies and Approaches for Mobilising Scaled-up Finance of 2013 (MSF) and 2014 (MSF2). ${ }^{3}$

Biennial Reports are formulated by developed countries only. They should include complete, transparent, accurate, comparable, and consistent information on a variety of issues including emission reductions and the provision of financial, technology, and capacity-building support to developing countries, and, "to the extent possible", on bilaterally leveraged private climate finance. ${ }^{4}$ Furthermore, developed countries should report on policies and measures that promote the up-scaling of private investment in mitigation and adaptation activities in developing countries (UNFCCC 2011: Decision 2/CP.17, paragraphs 12-22). This may lead to an incomplete picture, since BRs do not cover private finance mobilised by multilateral funds including the PPCR, the Global Environment Facility, and in the future the GCF (Iro 2014).

Therefore, this paper also analyses MSF submissions. In the context of the challenge to mobilise $\$ 100$ billion per year by 2020, developed countries were invited in 2012 to provide information on their strategies and approaches towards this goal (UNFCCC 2013c: Decision 1/CP.18, paragraph 67). Given the lack of guidelines, submissions vary significantly in structure and length (between 3 and 81 pages).

Only Canada, Japan, New Zealand, Norway, and the USA (as countries) and the EU (as a group of countries) submitted all four documents. Together, they represent 21 out of all 24 "Annex II Parties": countries that committed to providing climate finance to developing countries in the 1992 UNFCCC. They represent 95\% of the Gross Domestic Product, 96\% of the emissions, and 97\% of the population of all Annex II Parties (World Bank 2015). ${ }^{5}$

Second, findings were triangulated and deepened through semi-structured interviews with climate finance and adaptation experts from bilateral and multilateral development banks and development agencies between November 2014 and March 2015. Here, the focus was on organisations that are predominantly or fully owned by developed countries and inherited from the development regime (i.e. not climate funds such as the GCF or the Adaptation Fund). These organisations are more likely to argue from a developed country perspective given their donor-driven decision-making processes (see Gupta 1995; Kilby 2006; Neumayer 2003). The interviews were essential for two reasons. First, the analysed documents are likely to be partly politically motivated. Although this helps to understand the framing of developed countries, it might be at the cost of content. Second, policies do not only live in the formal texts that define them, but also in the ways in which they are applied on a daily basis in the form of rules, local practises, procedures, and guidelines (Best 2012a). The interviews addressed both issues and added important practical and

\footnotetext{
${ }^{2}$ References to those documents in this paper will be according to these abbreviations: BR1: First biennial reports (UNFCCC 2014a); BR2: Second biennial reports (UNFCCC 2016).

${ }^{3}$ References to those documents in this paper will be according to these abbreviations: MSF1: Submissions from Parties to the COP (UNFCCC 2013b); MFS2: Submission Portal (UNFCCC 2014b).

4 "Leveraging" and "mobilising" are often used interchangeably (see, e.g. Brown et al. 2011; Stadelmann et al. 2011). Following Caruso and Ellis (2013), this paper uses the term "mobilise" in the political context of the $\$ 100$ billion climate finance commitment, and "leverage", only in reference to financial instruments. It mostly refers to private finance (see Table 2).

5 The EU is an Annex II Party, but not all its Member States are. These percentages do not include those EU countries that are not Annex II Parties, such as Poland and Slovakia.
} 
experience-driven layers to the perspectives. Thirteen experts were interviewed from the Asian Development Bank (ADB), Agence Française de Développement (AfD), Deutsche Investitions- und Entwicklungsgesellschaft (DEG), European Investment Bank (EIB), Inter-American Development Bank (IDB, two interviews), Global Environment Facility (GEF), Deutsche Gesellschaft für Internationale Zusammenarbeit (GIZ, two interviews), International Finance Corporation (IFC) of the World Bank Group, Japan International Cooperation Agency (JICA), Kreditanstalt für Wiederaufbau (KfW), and USAID. This limited number of semi-structured interviews allowed for an in-depth, "within-case" analysis to better understand causalities (cf. Gschwend 2007). Only experts from donor organisations were interviewed because this paper investigates the positions of developed countries and development banks and agencies.

Draft interview questions were first discussed with three researchers working on adaptation and global environmental governance and were pretested with a climate finance expert from a development bank (not included as an interviewee). The interviewees were carefully selected. Just like the author, most of them observe and participate in climate finance workshops and conferences within and outside of the UNFCCC regime. Some interviewees were recommended by their peers or superiors. All interviewees are either active in adaptation projects, or have in-depth knowledge about their organisations' projects because their position requires this. The sample of interviewees is representative: it covers a large share of a limited target group that is active in many different regions in the world. The interviewees were guaranteed anonymity in order for them to speak more freely.

\section{Political and practical perspectives}

This section describes motivations to mobilise private adaptation finance; recent practices; actors, instruments and modalities; and tracking of mobilised private adaptation finance in four subsections. Each subsection provides the perspectives of developed countries (based on the BRs and MSFs); critical reflections by respondents from development banks and agencies; as well as implications of the results for the climate finance system based on the fragmentation typology by Biermann et al. (2009).

\subsection{Motivation for private adaptation finance}

All analysed countries want to mobilise private finance in order to reach the $\$ 100$ billion commitment. The EU (MSF1: 63) describes private finance mobilisation as "a key part" and Japan (MSF1: 1) as "essential". Japan (BR2) states to have mobilised \$3.6 billion of private finance in 2013-2014, but this was predominantly mitigation finance.

Most countries provide additional motivations for mobilising private finance (see Table 1). The EU, New Zealand, and Norway consider private finance key to limit global warming to $2{ }^{\circ} \mathrm{C}$. The EU, New Zealand, Norway, and the USA mention the importance of the private sector for countries' transition to low-carbon and resilient economies. Some countries make it clear that public funding alone is insufficient for the challenge of climate change. The US (BR1; BR2) calls its public resources "significant, but finite" and Norway (BR2) points out that the dominant global financial flows are private. Japan furthermore states that private finance is "crucially important" for large investments, such as infrastructure projects (BR1: BR2). 
Table 1 Developed country motivations to include the private sector as a source of climate finance as described in BR1, BR2, MSF1, and MSF2

\begin{tabular}{lllll}
\hline & $\begin{array}{l}\text { Meet } \$ 100 \text { billion } \\
\text { commitment }\end{array}$ & $\begin{array}{l}\text { Transition to low-carbon } \\
\text { and resilient economies }\end{array}$ & $\begin{array}{l}\text { Meet } 2{ }^{\circ} \mathrm{C} \\
\text { target }\end{array}$ & $\begin{array}{l}\text { Finance large- } \\
\text { scale projects }\end{array}$ \\
\hline Canada & 2 & 0 & 0 & 0 \\
EU & 3 & 3 & 1 & 0 \\
Japan & 2 & 0 & 0 & 2 \\
New Zealand & 1 & 1 & 2 & 0 \\
Norway & 1 & 2 & 1 & 0 \\
USA & 1 & 2 & 0 & 0 \\
\hline
\end{tabular}

The numbers in the table indicate the number of submissions by a country providing this motivation

Despite arguing for the importance of mobilised private finance, countries do not define mobilised private adaptation finance in their submissions. The interviews confirm this. Only two respondents state that developed countries sufficiently define private adaptation finance. One respondent states that the OECD's Development Assistance Committee (DAC) offers tangible criteria to measure public climate finance, which should be elaborated to include private finance in the future. The other respondent states that a vague definition can be interpreted in multiple ways, thus allowing his organisation to be opportunistic. Ambiguous policies that leave room for interpretation can indeed help international organisations to be more functional and have more power (Best 2012b). Such ambiguity, however, also contributes to a proliferation of activities labelled as adaptation and to difficulties in tracking and monitoring adaptation assistance (Hall, this issue). Most respondents state that adaptation is a vague concept; five respondents emphasise that the UNFCCC has not defined private adaptation financing. Four respondents state that at least there should be a differentiation between private investors that provide adaptation finance and businesses that implement adaptation, and between sector types and private actors (e.g. small enterprises and infrastructure).

The respondents are sceptical about developed countries' motivations for mobilising private finance for adaptation. Several respondents interpret the emphasis on private finance as a strong signal to involve the private sector in projects. However, all respondents find the provided motivation of reaching the $\$ 100$ billion commitment counterproductive. This is considered a global negotiation issue to which, according to some respondents, both the private sector and project managers at development banks are indifferent in their dayto-day activities. Several respondents furthermore state that the " $2{ }^{\circ} \mathrm{C}$ target" relates to mitigation only. The "transition", which is more dominant in later reporting, was appreciated. Two respondents point to the important role private finance could play here.

The development banks and agencies instead cooperate with the private sector to fulfil their pre-existing development mission, including sustained creation of jobs, financial sector development, and economic growth. Resilience is crucial for development. As one respondent from a multilateral development bank states: "a country cannot be resilient if the private sector is not resilient'” (Interview, 25 March 2015). Issues such as stability and the prevention of climate refugees, among others, are side benefits. Also, three respondents state that it is impossible not to cooperate with the private sector in one way or another in adaptation projects. These statements refer to businesses that implement adaptation (either 
autonomous or financed through public climate finance) rather than to private investors that provide adaptation finance.

In summary although there is no synergy between developed countries and the interviewed development banks and agencies on the definition of private adaptation finance and the motivation to mobilise it, there is no conflict either. This can be attributed to the ambiguous delegation from developed countries: it provides development banks and agencies with flexibility in their adaptation projects with the private sector (cf. Hall, this issue).

\subsection{Recent practice}

The developed country documents analysed in this paper focus on recent practices with mobilising private mitigation finance and say little about mobilised private adaption finance. Japan mobilised some private adaptation finance through trade insurance and cofinancing by the Japan Bank for International Cooperation (JBIC) (BR1). Japan also states that adaptation projects tend to generate relatively little financial return to the private sector compared to mitigation projects, and that many adaptation projects do not deliver a financial return at all (MSF1). Canada (BR1: 244) states that "there are a number of potential barriers to facilitating sufficient private investment". Yet it hardly describes such barriers or how to overcome them. Canada contributes much of its climate finance to multilateral organisations (including the IFC, IDB and ADB), thus outsourcing its mobilisation of private climate finance (see BR2).

New Zealand (MSF1) and Norway (BR1) do report on adaptation projects undertaken in cooperation with the private sector. Yet instead of financing, the private sector was implementing projects. This mirrors the differentiation that many respondents refer to, as explained in the previous subsection. Pauw (2014) also illustrates this: in the agricultural sector in Zambia, the (domestic) private sector can implement adaptation, but few opportunities exist for (international) private financing of adaptation.

Finally, although all countries emphasise the importance of strategy development and capacity building for adaptation, they do not involve the private sector here. For example, the EU does not mention the private sector when it explains its strengthened support for building human and technical capacity (BR1). The US (BR1; BR2) aims to engage the private sector through capacity building and strategy development in developing countries, but examples of its assistance focus on partner governments and civil society, even though the for-profit private sector has much more investment potential than the non-profit private sector. Finally, Japan (BR1: 83) claims to have developed its fast-start finance projects in "close consultation" but examples of this only refer to developing country governments and international organisations.

Although respondents confirm that there is very little experience with leveraging private adaptation finance, two-thirds report examples of public-private cooperation on adaptation, either with private investors or with businesses that implement adaptation (actors, instruments, and modalities will be discussed in the next subsection). Examples come from the following sectors: agriculture (five times); water management; water-intensive industries; infrastructure (all twice); insurance; financial sector; and tourism (all once). Such cooperation leads to private implementation of adaptation, and inherently to private expenditure too. Yet the respondents could usually not tell how much the private counterpart spent on adaptation. Indeed, accounting of such expenditure as private adaptation finance is difficult (Atteridge and Dzebo 2015; Brown et al. 2015). 
Only one development bank official mentions an example where private finance was leveraged-with a ratio of 1:2. The bank covered the full incremental costs of adaptation and the private investor only covered the business-as-usual investment. Discussions on the share of such investments that could count as adaptation finance have hardly started (see Sect. 3.4; Hall, this issue). Respondents generally see possibilities to mobilise private investments when co-benefits can be created, such as reduced water or energy use. In this context, they mention water management (twice); tourism (once); and agriculture (once). Furthermore, respondents mention service sectors (e.g. insurance, information services, risk assessments (all once)) and large-scale infrastructure projects with revenue streams, such as through toll roads (once).

Most respondents state that it is crucial for private sector involvement in both financing and implementing adaptation to build capacity (six times); raise awareness and provide information (three times); provide guidance in initial phases of projects (twice); and demonstrate successful adaptation to promote up-scaling and replication (once). Some respondents state that although the private sector might have experience with weatherrelated disasters such as heat waves and floods, it still needs to develop greater awareness and understanding about climate change. One respondent states that public-private partnerships can be a good vehicle here. For example, the IFC financed a $\$ 200,000$ study on adaptation options for a port in Colombia. Its outcomes led to a private $\$ 20$ million investment, financed through a commercial loan (Druce et al. 2016). Furthermore, three respondents emphasise that capacity building also helps the public sector to better understand the private sector perspective on adaptation.

This section showed that most cooperation with the private sector on adaptation so far relates to implementation (and inherently to private expenditure on adaptation), rather than to private adaptation financing. Although this might conflict with the first aim in Table 1 (reaching the $\$ 100$ billion commitment), it does not conflict with the second aim (mobilising private investments for a transition towards climate-resilient economies). Furthermore, the conflict on the mobilisation of $\$ 100$ billion of climate finance and the perceived importance of capacity building indicate a cooperative but incomplete actor constellation. Many private actors have a limited understanding of adaptation, and an even lower awareness on (discussions about) private adaptation finance at the UN climate change negotiations (cf. Pauw et al. 2015).

\subsection{Actors, instruments, and modalities}

Most analysed countries acknowledge that they have to move forward together and with the private sector in order to reach the $\$ 100$ billion commitment. The countries also emphasise the importance of enabling environments. However, neither the "partnership" nor the enabling environments are elaborated in detail.

Canada, Japan, and the USA point to the importance of multilateral channels to leverage private finance. In their MSF2, the EU, Japan, and the USA signal the importance of the newly established Private Sector Facility of the GCF. The EU (MSF1) focuses on support for small and medium enterprises in developing countries. Most emphasis, however, is put on both domestic and developing country governments that need to create an enabling environment for the mobilisation of private adaptation finance. Stenek et al. (2013) structure enabling environments along five categories: provision of (weather and climate) data and information; institutional arrangements (e.g. partnerships); conducive policies (e.g. technical standards and zoning regulations); economic incentives (e.g. taxes and subsidies); and communication and technology (e.g. encouraging knowledge and 
technology transfer). These are generally to be addressed domestically, but they can also be organised or supported internationally (Pauw 2014).

Domestically, for example, the EU (MSF1: BR1) plans to mainstream climate policy into public and private investments to reduce risks of investments, build capacity, and develop a project pipeline. In an international context, Canada (BR1) considers capacity building and the development of financeable projects an effective use of climate finance. New Zealand (MSF1) proposes to increase private adaptation finance by encouraging and supporting developing countries to develop strategies in order to provide the private sector the confidence and policy certainty to make investments. The EU (MSF1: 2) also states that "countries with a sound climate policy framework are well positioned to attract international and domestic climate finance" and support developing countries to build capacity to attract climate finance.

The USA, Japan, and Norway take a harder stance. The USA emphasises developing countries' own responsibility when stating that "strategies for mobilizing finance in and to developing countries will be incomplete without developing countries doing their part to strengthen domestic enabling environments" (MSF1: 3). Japan (MSF1) explicitly mentions the limited enabling environment in developing countries (including a lack of hard and soft infrastructure) as the main barrier to scale up private finance in climate change mitigation and adaptation. Norway goes one step further. According to Norway, effective climate action by developing countries and these countries' steps to improve enabling environments (which should be "fuelled by national self-interest") are even a requirement for the $\$ 100$ billion commitment to be met (MSF1: 7). This statement puts the responsibility to mobilise finance partly in the hands of the recipients.

All respondents acknowledge the importance of a favourable enabling environment for adaptation. On a very practical level, two respondents for example state that it would be useful to list and describe all potential adaptive measures - in particular those that lower the costs of production - and to showcase replicable and easy-to-understand projects.

However, respondents put more emphasises on the importance of the broader context when implementing adaptation projects with the private sector for three reasons. First, three respondents point out that much of the enabling environment for private climate finance actually depends on the general business environment. This goes beyond the five categories of Stenek et al. (2013) and includes for instance low levels of bureaucracy or good transport and IT infrastructure.

Second, respondents emphasise that enabling environment should encompass more than adaptation alone, because both public and private actors are often unfamiliar with the concept of adaptation. Two respondents note that the specifics of private adaptation are unclear even to countries that make an effort to create an enabling environment for private climate finance. Two other respondents state that it is irrelevant for the private sector whether investments that contribute to adaptation (based on expert judgement) are actually labelled as such. In general, most respondents themselves also refer to increasing resilience and reducing vulnerability, rather than to adaptation.

Finally, respondents point to the difference between global climate negotiations and the level of project implementation. For example, the analysis above shows that enabling environments for private investments are imperative for developed countries in the UNFCCC negotiations. Here, there is a norm conflict with many developing countries: four respondents state that many developing countries oppose the general notion of private adaptation finance at the UNFCCC negotiations (the author also observed this repeatedly). However, on the level of implementation, such political standpoints on private adaptation finance are less relevant. Half of the interviewees are under the impression that developing 
countries even prefer private investments over public finance, given that the private sector can create longer-term jobs, economic development, and tax revenues.

Instruments to leverage private finance that countries mention are skewed towards mitigation. The analysed submissions scarcely mention instruments to leverage private adaptation finance and generally not describe details (see Table 2). Canada (MSF1: 3) for instance writes that "insurance and other market-based approaches can help address those adaptation risks that are financeable". Japan (MSF1) mentions concessional loans and insurance mechanisms. More concretely, Japan is working on standby loans for disaster recovery and weather-related insurance provided by private companies. The EU (MSF1) states that it has finance instruments that target specific market failures and that are designed not to crowd out or over-subsidise the private sector. It describes the use of grants to leverage public finance (including official development assistance) and private sector financing though regional blending mechanisms. Instruments for this purpose include grants, technical assistance, interest-rate subsidies, risk capital, and guarantees. Although the blending facilities have mainly supported public investments so far, the EU intends to increase the use for facilitating private sector participation.

Canada (MSF1), New Zealand (MSF2), and the USA (BR1; BR2) state that public grant support should be considered where affordable market-based financing is not available, for example for adaptation in the poorest and most vulnerable countries. Yet the US (BR1; BR2) also turns the argument around by stating that such means can be made available if private finance can be leveraged more efficiently elsewhere. Canada (MSF1) furthermore states that non-grant financing, including (concessional) loans, should be the primary choice in middle-income countries or where the private sector is involved. Japan (MSF1:3) on the other hand separates public and private responsibilities (and consequently financing) when it states that "private companies basically seek to invest in projects which deliver a financial return without receiving public assistance", but that the private sector does expect public support through enabling environments in developing countries.

Finally, all countries use non-financing instruments such as technology transfer and capacity building. However, only the US (BR1) and Norway (BR1) mention this instrument in the context of leveraging private finance with examples on mitigation only.

Respondents provided different views on financial instruments. First, they did not mention examples of export credit and guarantees. A potential explanation is that these instruments are not within their mandates.

Table 2 Financial instruments to leverage private adaptation finance, as described in BRs and MSFs

\begin{tabular}{|c|c|c|c|c|c|}
\hline & Canada & EU & Japan & Norway & USA \\
\hline Non-financial instruments & & 2 & 2 & 1 & 2 \\
\hline Grants & 2 & 2 & 1 & & 2 \\
\hline Guarantees & & 2 & 1 & & 2 \\
\hline Concessional loans & 2 & & 2 & & \\
\hline Insurance & 2 & & 2 & & \\
\hline Loans & 2 & & 2 & & \\
\hline Export credit & 1 & & & & 1 \\
\hline Lines of credit & & 1 & & & \\
\hline
\end{tabular}

A " 2 " indicates a country elaborates on an instrument at least once. A "1" means a country mentioned an instrument without elaborating on it. New Zealand did not describe specific instruments 
Second, respondents put more emphasis on loans (mentioned six times) and lines of credit (three times). Through the latter, development banks finance local private banks and other intermediaries in developing countries, which on-lend the credit to private endborrowers that would otherwise struggle to get finance. Two respondents from development banks however state that it is not in their mandate to finance the private sector directly.

Finally, in contrast to the analysed developed countries, most respondents emphasise that technical assistance is crucial in projects, and one respondent mentions green bonds. Technical assistance, both for financial institutions and for those who implement adaptation projects, can be financed through grants. Bonds are mentioned in the context of cities with comprehensive adaptation strategies. If related adaptation measures have a return on investment, or if a city plans to finance them publicly anyway, bonds could frontload investments.

To summarise the implications for the fragmented climate finance system: developed countries and the development banks and agencies share the norm that enabling environments are important to mobilise private adaptation finance and private adaptation implementation. However, there are different views on the importance of enabling environments for adaptation, even between countries. Just like the minor differences in the instruments that countries and development banks and agencies refer to, this does not cause conflicts for the institutional integration, norms, or actor constellations. A more important contrast, however, seems to be that at a local level, development banks, and agencies perceive that they have synergies with developing countries when it comes to adaptation projects with the private sector. In global climate change negotiations, however, there is a norm conflict between developed countries (advocating for private finance) and developing countries (disapproving of it).

\subsection{Tracking private adaptation finance}

Measurement, reporting, and verification (MRV) of climate finance helps to gain a better overall understanding of its scale, distribution, and use. It is technically complex and touches upon highly political and sensitive definitional questions (Iro 2014). Currently, there is limited publicly available data on private adaptation finance mobilised by public interventions in and to developing countries (UNEP 2016), and there is no agreed definition on how to account for private adaptation finance (Brown et al. 2015; Buchner et al. 2015; Vivid Economics 2015).

The EU (MSF1) emphasises the need to advance towards an agreed definition as well as accounting and monitoring of private climate flows. It mentions the complexities surrounding data availability, the multitude of actors involved, diverse channels of finance, and rapidly fluctuating activities. According to the EU (MSF1), a common understanding of private climate finance is necessary to ensure transparency and trust. The EU expresses support to ongoing research on this matter, and, just like Japan (MSF1) and Canada (MSF1), states that this process should be gone through in close cooperation with other donors.

Canada (MSF1), Norway (MSF1), and New Zealand state that there should be a focus on outcomes; according to New Zealand (MSF1), this would ensure that the results of climate finance interventions can be tracked and reported. Norway (MSF1) states that a focus on outcomes also makes developing country partners accountable for reaching desired climate results. 
New Zealand and the USA also criticise tracking. For example, New Zealand (MSF1) states that burdensome reporting and application procedures can deter uptake and further mobilisation of climate finance. The USA points to the range of actors involved and the vast variety of financing tools and policies needed to enable mitigation and adaptation activities. According to the USA (BR1: 1), this should be recognised, "rather than seeking overly simplified solutions focused on a particular delivery channel, sector, or financing approach". At the same time, however, the USA only describes three financial instruments in their submissions (see Table 2).

All respondents' organisations report their climate finance contributions using the OECD-DAC Rio Markers. Although these markers were originally introduced by the OECD-DAC to indicate donor's environmental policy objectives in development cooperation (Iro 2014), they are also used to measure climate finance. Some respondents state that their organisations also monitor and report because of internal targets on financing (for instance renewable energy or climate, twice); because they want to demonstrate that the organisation is an important player in climate finance (twice); or because of accountability towards taxpayers (once).

However, only four respondents mention that their organisation reports on mobilised private adaptation finance, emphasising how difficult this is. The respondents provide three reasons for this: first, internal lack of preparedness. One organisation undertook a reporting exercise before the UN Climate Summit in New York in 2014. According to the respondent, this exercise clarified that there is currently no information available on mobilised private adaptation finance. Future monitoring and reporting would require a new system to be built up; second, limited willingness from the private sector to undertake MRV. Apart from an administrative burden, two respondents also mention confidentiality and competitiveness as potential issues for the private sector. Third, three respondents mention that without a clear definition of adaptation finance, MRV will be difficult and perhaps not very useful. For example, two respondents state that their institution covers the incremental costs of adaptation. Similarly, one development bank covered the costs to climate-proof a road. Strictly speaking, the private sector's share (the road itself) is not invested in adaptation. In another example, three respondents highlight that the MDBs currently use different methods in their common reporting system. This system (see EIB 2014) takes vulnerability reduction as a starting point rather than adaptation, which could result in an overestimate of mobilised adaptation finance. Reporting based on different methods cannot provide final answers in terms of contributions to the $\$ 100$ billion commitment.

In terms of the climate finance system, the most conflictive consequences of fragmentation identified in this paper relate to the accounting of mobilised private finance towards the $\$ 100$ billion commitment. Such accounting would require a cooperative (if not synergistic) actor constellation. However, respondents see limited willingness from the private sector to be part of MRV in the climate finance system. Furthermore, respondents use different reporting systems themselves. Finally, developed countries disagree on the importance and aim of tracking mobilised private finance.

\section{Discussion and conclusion}

This paper analyses the position of developed countries as well as development banks and agencies towards private adaptation finance. It shows that there is a discrepancy between the former's position in submissions to the UN climate negotiations, and the latter's 
understanding and local implementation of private adaptation and adaptation finance (see Table 3). This paper shows that this discrepancy is a consequence of the fragmented climate finance system.

In submissions to the UNFCCC, developed countries focus on the private sector in general. They aim to mobilise private finance to reach the $\$ 100$ billion commitment, and for a transition to low-carbon and climate-resilient economies. At the level of implementation, these objectives prove to be too abstract. Here, respondents' organisations instead cooperate with the private sector to implement adaptation actions, in order to increase resilience or reduce vulnerability.

Furthermore, at the level of implementation, development banks and agencies perceive that they have scope for cooperation with developing countries: they have the impression that developing countries also want to include the private sector in adaptation projects, as it creates jobs, economic growth, and tax revenue. In the global climate change negotiations, however, norm conflict remains between developed countries (advocating for private finance) and developing countries (often disapproving of it).

Second, in line with Pauw et al. (2015), this paper concludes that the diplomatic UNFCCC language around private adaptation finance differs from the private sector reality. Respondents highlighted the private sector's low awareness of political aspects and conceptualisations of adaptation, but stated that the private sector does have practical experience in addressing climate-related hazards such as heat waves and flooding. Therefore, respondents do see potential for private investments in resilience in a variety of sectors, including in developing countries. According to the respondents, technical assistance could increase the private sector's understanding of climate change and stimulate private investment in adaptation. This need for technical assistance, in combination with the limited mobilisation of private adaptation finance so far, shows that the private sector is not integrated in the climate finance system. One limitation of this study is that private sector actors were not interviewed themselves. This was not necessary for the aim of this

Table 3 Discrepancy between developed countries' submissions to the UN climate negotiations and the respondents of development banks and agencies in relation to private sector engagement in adaptation finance

Level

\begin{tabular}{|c|c|c|}
\hline & $\begin{array}{l}\text { Developed country } \\
\text { communication to UN climate } \\
\text { negotiations }\end{array}$ & $\begin{array}{l}\text { Implementation according to respondents } \\
\text { from development banks and agencies }\end{array}$ \\
\hline $\begin{array}{l}\text { Main motivations for } \\
\text { private engagement }\end{array}$ & $\begin{array}{l}\text { Mobilise } \$ 100 \text { billion per year } \\
\text { Transformation to low-carbon } \\
\text { and climate-resilient economies }\end{array}$ & $\begin{array}{l}\text { Implementation of projects } \\
\text { Sustained creation of jobs } \\
\text { Development of the financial sector } \\
\text { Economic growth }\end{array}$ \\
\hline $\begin{array}{l}\text { Private actors } \\
\text { involved }\end{array}$ & $\begin{array}{l}\text { "Private sector" in general } \\
\text { No differentiation between } \\
\text { private sector financing and } \\
\text { implementation }\end{array}$ & $\begin{array}{l}\text { Predominantly private implementation of } \\
\text { adaptation (rather than finance) } \\
\text { Need to specify sectors } \\
\text { Need to specify types of private entities }\end{array}$ \\
\hline $\begin{array}{l}\text { Perception of } \\
\text { position of } \\
\text { developing } \\
\text { countries }\end{array}$ & (Not included in submissions) & $\begin{array}{l}\text { Private sector engagement wanted, sometimes } \\
\text { preferred over public finance as it can create } \\
\text { jobs, tax revenue, and economic growth }\end{array}$ \\
\hline
\end{tabular}


paper, but it would be necessary for a more comprehensive analysis of the private sector's limited integration in the climate finance system.

The above-mentioned discrepancy illustrates how fragmented the climate finance system is. It also demonstrates the ambiguity around concepts such as "private adaptation finance", "enabling environment". and "mobilising" (see also Hall, this issue). As long as such concepts remain ambiguous, actors' key norms can differ without conflict. This could facilitate the inclusion of a broad set of actors and policy approaches. It may also enhance innovation at the level of a public agency and increase innovation in the entire system (Biermann et al. 2009).

However, if the aim of mobilising private finance is to reach the $\$ 100$ billion commitment, the climate finance system requires a more static and integrated architecture. It would need clear definitions on concepts (including mobilised private adaptation finance); accounting rules (what counts?) as well as attribution rules (who mobilised?). This will cause norm conflicts between important actors, given the technical difficulties in quantifying the mobilisation effect of public interventions (see Brown et al. 2015; Jachnik et al. 2015) and political struggles in agreeing on how to account for private finance as part of the $\$ 100$ billion commitment in the UNFCCC regime. Furthermore, it would require a cooperative (if not synergistic) actor constellation, but respondents perceive a low willingness from the private sector to be part of the climate finance system.

Alternatively, the aim could be output: maximising the mobilisation of effective private investments (rather than finance) in resilience and reducing vulnerability, regardless of whether these constitute climate finance or not. In addition to the historical focus on support for private investment at the project level (e.g. through grants, concessional lending, and equity investments that can be accounted for), such "aiming for output" could also address the increased awareness of the need for interventions at market level (cf. Whitley 2014). An analysis of the idea that the private sector can make a substantial contribution to adaptation finance can still be done at a later stage once more practical experience exists.

Adaptation finance is not an end in itself, but only a means towards adaptation. Rather than being fixated on reaching the $\$ 100$ billion commitment, the climate finance system should aim for adaptation output. This might also enhance innovation and include more actors in the system.

Acknowledgements I am indebted to all those who generously gave their time to be interviewed and engaged in this research. I would like to thank Jakob Skovgaard and Lund University for inviting me to the Lund climate finance workshop to present and discuss this paper; and Carola Betzold, Frank Biermann, Katrin Enting, Prosanto Pal, Jonathan Pickering, Jakob Skovgaard, Pier Vellinga, and three anonymous reviewers for their excellent comments and suggestions for improvements. Finally, the author acknowledges the German Federal Ministry for Economic Cooperation and Development for financial support.

Open Access This article is distributed under the terms of the Creative Commons Attribution 4.0 International License (http://creativecommons.org/licenses/by/4.0/), which permits unrestricted use, distribution, and reproduction in any medium, provided you give appropriate credit to the original author(s) and the source, provide a link to the Creative Commons license, and indicate if changes were made.

\section{References}

Abadie, L. M., Galarrage, I., \& Rübbelke, D. (2012). An analysis of the causes of the mitigation bias in international climate finance. Mitigation and Adaptation Strategies for Global Change, 18, 943-955. 
Atteridge, A. (2011). Will private finance support climate change adaptation in developing countries? Historical patterns as a window on future private-sector climate finance. Working Paper No. 2011-05: 38. Stockholm Environment Institute, Stockholm.

Atteridge, A., \& Dzebo, A. (2015). When does private finance count as climate finance? Accounting for private contributions towards international pledges. SEI Discussion Brief, Stockholm.

Ayers, J. (2011). Resolving the adaptation paradox: Exploring the potential for deliberative adaptation policy-making in Bangladesh. Global Environmental Politics, 11(1), 62-88.

Best, J. (2012a). Ambiguity and uncertainty in international organizations: A history of debating IMF conditionality. International Studies Quarterly, 56, 674-688.

Best, J. (2012b). Bureaucratic ambiguity. Economy and Society, 41(1), 84-106.

Biermann, F., Pattberg, P., van Asselt, H., \& Zelli, F. (2009). The fragmentation of global governance architectures: A framework for analysis. Global Environmental Politics, 9(4), 14-40.

Brown, J., Buchner, B., Wagner, G., \& Sierra, K. (2011). Improving the effectiveness of climate finance: A survey of leveraging methodologies. Climate Policy Initiative.

Brown, J. Stadelmann, M., Wang, D., Boni, L., Jachnik, R., \& Kato, T. (2015). Estimating mobilized private finance for adaptation: Exploring data and methods. CPI and OECD.

Brunner, S., \& Enting, K. (2014). Climate finance: A transaction cost perspective on the structure of state-tostate transfers. Global Environmental Change, 27, 138-143.

Buchner, B., Trabacchi, C., Mazza, F., Abramskiehn, D., \& Wang, D. (2015). Global landscape of climate finance 2015. Venice: Climate Policy Initiative.

Caruso, R., \& Ellis, J. (2013). Comparing definitions and methods to estimate mobilised climate finance. Climate Change Expert Group Paper No. 2013(2). OECD and IEA, Paris.

Druce, L., Moslener, U., Gruening, C., Pauw, W. P., \& Connel, R. (2016). Demystifying adaptation finance for the private sector. UNEP Finance Initiative, Geneva.

Economics, Vivid. (2015). Building an evidence base on private sector engagement in financing climate change adaptation. London: Vivid Economics.

EIB. (2014). Joint Report on MDB climate finance 2014. Luxemburg: European Investment Bank.

Gschwend, T. S. F. (2007). Introduction: Designing research in political science-A dialogue between theory and data. Research design in political science: How to practice what they preach. Basingstoke: Palgrave Macmillan.

Gupta, J. (1995). The global environment facility in its North-South context. Environmental Politics, 4(1), $19-43$.

Intellecap. (2010). Opportunities for private sector engagement in urban climate change resilience building. Hyderabad: Intellecap.

IPCC. (2014). Climate change 2014: Impacts, adaptation, and vulnerability. part A: Global and sectoral aspects. Contribution of working group II to the fifth assessment report of the intergovernmental panel on climate change. Cambridge: Cambridge University Press.

Iro, A. (2014). Measuring, reporting and verifying climate finance: International state of play and future perspectives. Deutsche Gesellschaft für Internationale Zusammenarbeit (GIZ) GmbH, Eschborn \& Bonn.

Jachnik, R., Caruso, R., \& Srivastava, A. (2015). Estimating mobilised private climate finance. OECD Environment Working Paper No 83. OECD, Paris.

Kilby, C. (2006). Donor influence in multilateral development banks: The case of the Asian Development Bank. The Review of International Organizations, 1(2), 173-195.

Neumayer, E. (2003). The determinants of aid allocation by regional multilateral development banks and United Nations agencies. International Studies Quarterly, 47(1), 101-122.

Pauw, W. P. (2014). Not a panacea: Private-sector engagement in adaptation and adaptation finance in developing countries. Climate Policy, 15(5), 583-603.

Pauw, W. P., Klein, R. J. T., Biermann, F., \& Vellinga, P. (2015). Private finance for adaptation: Do private realities meet public ambitions? Climatic Change, 134(4), 489-503.

Project Catalyst. (2010). Making fast start finance work. Briefing Paper (June 2010 version). Climate Works Foundation \& European Climate Foundation.

Romani, M., \& Stern, N. (2011). Delivering climate finance: Principles and practice for funding the Fund. London: Grantham Institute.

Stadelmann, M., Castro, P., \& Michaelowa, A. (2011). Mobilising private finance for low-carbon development. Tackling barriers to investments in developing countries and accounting of private climate flows. Climate Strategies, London.

Stenek, V., Amado, J. C., \& Greenall, D. (2013). Enabling environment for private sector adaptation: An index assessment framework. Washington: International Finance Corporation.

Surminski, S. (2013). Private-sector adaptation to climate risk. Nature Climate Change, 3(11), 943-945. 
UNEP. (2016). The adaptation finance gap report. Nairobi: United Nations Environment Programme.

UNFCCC. (2009). Decision 2/CP.15. Copenhagen Accord. Document FCCC/CP/2009/11/Add.1.

UNFCCC. (2011). Decision 2/CP.17. Outcome of the work of the Ad Hoc Working Group on Long-term Cooperative Action under the Convention. Document FCCC/CP/2011/9/Add.1.

UNFCCC. (2013a). Report on the outcomes of the extended work programme on long-term finance. Note by the co-chairs. Document FCCC/CP/2013/7.

UNFCCC. (2013b). Submissions from Parties to the COP. http://unfccc.int/documentation/submissions_ from_parties/items/5916.php. Accessed February 6, 2016.

UNFCCC. (2013c). Decision 1/CP.18. Agreed outcome pursuant to the Bali Action Plan. Document. Document FCCC/CP/2012/8/Add.1.

UNFCCC. (2014a). First biennial reports. http://unfccc.int/national_reports/biennial_reports_and_iar/ submitted_biennial_reports/items/9356.php. Accessed February 6, 2016.

UNFCCC. (2014b). Submission portal. http://www4.unfccc.int/submissions/SitePages/sessions.aspx. Accessed February 6, 2016.

UNFCCC. (2016). Second biennial reports. http://unfccc.int/national_reports/biennial_reports_and_iar/ submitted_biennial_reports/items/7550.php. Accessed February 6, 2016.

UNFCCC Standing Committee on Finance. (2014). 2014 Biennial assessment and overview of climate finance flows report. Bonn: UNFCCC.

Whitley, S. (2014). Mapping climate-relevant incentives and investment at country level: A diagnostic tool to mobilise private climate finance. ODI Working Paper. Overseas Development Institute, London.

Whitley, S., \& Mohanty, R. (2012). The United States' private climate finance support: Mobilising private sector engagement in climate compatible development. ODI Background Note. Overseas Development Institute, London.

Whitley, S., \& Mohanty, R. (2013). Germany's private climate finance support: Mobilising private sector engagement in climate compatible development. ODI Background Note. Overseas Development Institute, London.

World Bank. (2015). World development indicators. http://data.worldbank.org/data-catalog/worlddevelopment-indicators. Accessed August 24, 2015.

Zelli, F., \& van Asselt, H. (2013). The institutional fragmentation of global environmental governance: Causes, consequences, and responses. Global Environmental Politics, 13(3), 1-13. 